\title{
The Research of the Development of Muslim Private Lending under the Influence of the Islamic Culture
}

\author{
Haiying Ma* \\ School of Economics, Northwest University for Nationalities, Lanzhou (730124), P.R.China \\ Ixmahaiying8888@163.com
}

Keywords: Private lending; Islamic culture; IsImic finance; Ethnic regions

\begin{abstract}
In recent years, the private lending in rural economy has experienced a rapid development. Its existence and development with distinct features were closely connected with social economy. Being an effective complementary form in rural financial system, the private lending to some extent met the need of rural economical development for capital. However, because it was beyond official supervision, the private lending also exerts negative effect. As different nationalities have different feature in history, the mode of production, language, culture, custom and so on, which make them, show the ethnic characteristics in different levels in the process of the economic activity. Among them, the Muslim private lending in China under the influence of the Islamic culture, because of the unique economic perspective and values, plays an active role in the Muslim economic and social development.
\end{abstract}

\section{Introduction}

In recent years, the domestic private lending showed a rapid development momentum, and the study of private lending is awake, emerged a lot of research about private. However, those researches have some shortcomings: Firstly, the study on private lending is mostly around the developed region, for minority nationality areas, especially in Muslim Islamic culture characteristic private lending research is so rare. Then, the argument of the relations between private lending and regional economic is more than the research about private lending from the geographical and cultural aspects. What's more, the researchers about private lending pay more attention to the effect from the economic benefits, not the social benefits. Therefore, this paper analyze the field of vision from the economic expansion of the social sphere, and research analysis the Islamic culture's effect to Muslim private lending systematically and summarize the function by the Muslim private lending with unique Transactions at this stage.

\section{The Basic Feature of Muslim Economic Behavior and Its Practice}

The Business System in Islamic Culture. Among the world's culture, the Islamic culture not only fully affirmed the status, function and values of the business, but also specified the behavior of business. Mainly includes: 1, Insist on mutual benefit, against harm others to benefit oneself. Islamic culture thinks the principle of mutual benefit fits the basic economy law in the circulation of commodities. 2, Insist on fair trade, as opposed to speculation. Islamic culture thinks the fair trade could promote circulation, make the market active, while the speculation could disrupt the market, impact circulation. 3, Insist on fair competition, against monopoly. Islamic culture advocated opening free market; making the market conform to the laws of nature and do as a good market does, in order to achieve self-adjusting and balanced state. Monopoly market is considered to be artificial factors of intervention in the free market. 4, Prohibit interest, encourage help each other. Islamic culture encouraged to make a profit, but prohibit charging the interest, because the afterwards to determine the profits stands for the success of entrepreneurial spirit, and also bring additional benefits.

The Mercantilism in Muslim Culture. The theory of encouraging commercial in Islamic culture has a profound impact on Muslim business. Islamic culture in the development of regulations for 
commercial activities is not only limited to system itself, business activity is a special form of Islamic culture; Muslim business trade is carrying under a series of rules and regulations. Islamic culture advocating business, respect for businessmen, Muslim is engaged in the business field and region also develops unceasingly, Muslim business gradually becomes long-distance trafficking and involved in many fields, Chinese Muslims affected by the ancestors, Inherit and carry forward the traditional that good at doing business, most people prefer doing business when they make their career choices, what's more they have inherent adaptability for market economy, meanwhile Muslims created a unique business sense of competition.

The Muslim Economic Practice in China under the Influence of the Islamic Economic Culture. In history, the Muslims that active in the road and sea on Silk Road have made great contributions to the economy boom and revenue of Tang, Song and Yuan dynasties. Muslims participated in the antique jewelry industry, fur, leather industry, catering, slaughtering and transportation when they back to China. After the Ming dynasty, Muslims settled in all over the China, but they Mainly concentrated in the Shanxi, Gansu, Ningxia, Qinghai, Xinxiang and other provinces. According to the prevailing socio-economic patterns, Muslim mainly engaged in agriculture, they operated some small business only when they in the slack season, this situation continued until the founding of New China. In the socialist transformation period after the foundation of New China, Muslim commercial activity was banned. At the beginning of the reform and opening up, Muslims give play to what they are good at, and start doing business, with their spirit of endure hardship, they engaged in trafficking and emerged a large number of represented of individual industrial and commercial households. They have flocked to the western pastoral regions; purchase the agriculture and animal husbandry products, and provide raw materials for the eastern provinces. Since two thousand years, with the tactic of west development. The Muslim masses firmly grasp the historical opportunity, expand sales field, expand distribution channels, the flowing commodities include all production and living supplies and agriculture and animal husbandry products in western national areas.

The Development of the Muslim Private Lending in China. Private lending is the oldest credit form that accompanied by the emergence and development of commodity economy, and it has a long history in China. Since tang dynasty, the rise of the Silk Road made the Muslim trade develop and boom, that makes the Muslim private lending develop. As early as the Yuan Dynasty official appointed by the Muslim businessman that provide certain funds by the authorities and service in the royal family and nobles in the Yuan dynasty. Muslim region economic development is relatively stable in the in the period of early Qing Dynasty to the Republic of China. Muslim private lending reached a peak period. According to history research, in 1905, only in Linxia had run 19 private lending organizations, the activity of private lending is evident. After the founding of new China, Muslims private lending once was disappeared in the socialist transformation. At the reform and opening up in 1987, the economic transformation from a planned economy to a market economy muslim private lending access to development opportunities, and obtained the fast development. Since 2000, under the support of the national policies, the speed of economic development in the northwest region reached a further acceleration; the vast majority of Muslims private lending economy in the region started the second startup, present a vigorous development momentum. During this period, with the gradual deepening of reform of the financial system, most of the state-owned commercial bank branches quit the county economy, the new financial institutions follow up slowly. In this condition, muslim private lending filled in the financing gap caused by the removal of formal financial, and obtained the considerable development. At the beginning of 2009, the survey we have done in four provinces 13 Muslim concentrated areas in Gansu, Ningxia, Qinghai, Xinxiang shows that in 2008, the private lending reached 39.4 billion Yuan in all, accounting for $41.39 \%$ of the loan balance of the financial institutions at the end of the year, relieved the fund demand of Muslim region in private lending economy and rural economic development effectively, played the role of the gleaning. 


\section{The Economic Principles and Pattern of Muslim Private Lending}

\section{The Principles of Muslim Private Lending.}

Prohibit Access to Various Forms of Interest. The prohibition of interest (Riba) is the central tenets of Muslim private; Islamic culture think that interest is associated with the repayment period of capital and the amount, and any positive, fixed, pre-determined interest rates are considered to be banned. Islamic culture in interest theory mainly includes the three followings: 1. Against the interest, prohibit unjust enrichment. Interest in the Islamic economic thought was defined as all the non-productive or does not contain value creation. 2. Refute the western economics point of view that interest as a money market price, against the way that money comes from money. 3. Money is just a potential capital, it only works as a capital, rather than as a potential capital.

Proposal Sharing the Investment Risk and Profit. Islamic culture thinks the currently prevailing in the world lending relationship obviously is advantageous to the lenders and do harm to debtor, the borrower must repay principal and interest at the prescribed rate and deadline no matter how the effect of management, however, the lenders do not take risks, so it is unfair. Therefore, they propose that capital providers should also be the investor; both borrowers and lenders share the risk of investment and sharing the profits from investments. Meanwhile, they encourage investing in the real economy, and prohibit the lending activities that have the virtual nature of the uncertainty of investment, and speculative, and pays attention to the use of the funds and the transparency of information disclosure, and minimize the risk of the funds farthest.

Encourage Relieving the Debts of Disadvantaged Groups. Islamic culture of Zakat system (the tax system) argues that the loaner can obtained more generous potential returns if they relief debt that belong to the poor or hard to repay, so in Muslim region usually adopt neutralizing attitude when the loaner safeguard legal rights in private. Creditors could relief the debts that the debtor cannot repay due to various objective reasons. There are some ways of relief: break some or all debts, extension time, pay debts by items and so on.

\section{The Concrete Manifestation of Muslim Private Lending.}

Interest-free Loans. Islamic culture thinks Muslim loan is the lender borrowers borrowed money, debtor pay back the borrowed money when they have the ability. Islamic culture thinks that borrowing is an effective way to strengthen relationships, and not only can help each other solve problems, but also can reflects the love and mercy among people, debtors repay lenders the same amount of money or the equal value property, and it meets the requirements of Islamic culture. They against make a living by borrow, all forms of interest is departure form Islamic culture. If the lenders have not put forward the requirement or the two sides have not reach an agreement that includes markon, the borrower pay back the better or the more property, in that way, we regards this kind of activities as voluntary of gratitude, in the license.

Partnerships. The partnerships in Islamic culture is a kind of operating procedure that two or more people in accordance with the agreement, joint investment, share the risk and profits. that is, the borrowers borrow certain money, they will not pay interest to the creditors according to the agreed interest rate, and they will share the risks and profits with creditors according to the operating condition. Such as six individual industrial and commercial users in Linxia, Gansu engaged in building materials in Tibet formed a relationship loan to each other for a long time, whenever there is a huge business opportunity, then some people would launch a borrowing, 7 times lending financing have been carried out successively in 2008, the largest amount reached 100 million Yuan at a time. In completed 7 times in financing activities, the participants gained profits from $-20 \%$ to $20 \%$.

Finance Lease. Which is when the enterprise or individual need purchase equipment, the lender purchases the equipment beforehand according to the borrower's willingness, and then leased to the borrower. If someone prepared to loan 150000 Yuan to buy a car to start transport career, the lender bought a150000-Yuan car according to the borrower's willingness, then leased the car to the borrower, they reached an agreement in the loan contract that the borrower repay 5000 Yuan a month for three 
years, the cumulative amount is 180000 Yuan, the vehicles owned by the borrower after the repayment.

Deferred Payment. Which is due to the borrowers' capital shortage, they will pay back some part of the loan after a certain period in the access to goods for repayment. This behavior occurs mainly in the wholesale trade, by a large wholesaler partial payment on credit to small wholesalers, and the small wholesaler return the balance the next time they buy goods, through this way of borrowing, both sides have mutual reciprocity and mutual benefit and they realize the win-win situation, in the case of a shortage of funds to complete the transaction and transfer of the goods

Payment in Advance. That is the activity that the buyer prepaid part of amount under such a presupposition that the both sides are consensual. Islamic culture emphasizes that the trade under advance payment must be a mutual mutually beneficial. Such as before the crops ripe, the rich need to purchase, farmers need cash for spending, deliver the cargo to the other party until the crops ripe. The advantage of this kind of way to trade is to benefit both sides.

Transfer Debt. That is the debtor can transfer the debt to repay the debt of the third party, Islamic culture thinks that can be completed as long as the both sides reach to an agreement, and there is no necessary to get consent of any third party. The reason is that the debtors return the debt by what kind of way is their right, as long as to get creditors agree.

\section{The Effects of Muslim Private Lending}

Since Song and Yuan dynasty, Muslim commercial trade gradually flourishing driven by huge impact of Muslim private, and remains a thriving condition in thousands years. It makes an irreplaceable contribution for promoting the economic and social development of Muslim region.

\section{The Economic Function of Muslim Private Lending}

Improved the Efficiency of Resource Allocation. The development of Muslim private lending makes the social capital get reassigned in a certain extent, and improve the efficiency of conversion from saving to investment. Especially the Muslim region has backward economic development, Low efficiency and small-scale enterprises, and lack of collateral, the majority of small and medium-sized enterprises have difficulty to get a formal financial support, there is a huge financing gap between credit capital requirements and the supply of formal financial. In this case, the continuous development of Muslim private, and the intervention of "cutting corners" type, meets the funds required for the production and life of the small and medium-sized enterprises and the majority people.

Avoiding the Risk of Capital Effectively. Participants of Muslim private lending a focus on the mobility, safety, and profitability of capital specially, and they have inherent market and competitive mechanisms and risk awareness, avoid the risk of capital effectively. Muslim private lending has superiority of Both borrowers and lenders have the same information, recognition with each other in financial terms, and flexible procedure in operation and management, In the effective support of the Muslim nation's rapid economic growth while also gained rapid development itself.

\section{The Social Function of Muslim Private Lending}

It can Improve Relationships and Promote Society Development Harmoniously. Passing friendship and affection, it could be a form of relationship when you borrowed to relatives, friends, neighbors, or this relationship may be interrupted or fractured. Then, it is a reflection of abiding by the law complying with the law that forgive the interest income of monetary form in the process of private, promote Society Development Harmoniously objectively. It can get initiative in some behavior in the interpersonal communication. lending money to others free of charge when others are in trouble, but the real purpose is get help from more people when he sink into this kind of things. 
Dishonesty Costs are high. Which is beneficial to improve the local credit environment. Muslims have good faith idea of Chinese civilization together, and there is the spirit of integrity, love, mutual aid advocated by Islamic culture. Family, affection, and customs blend into private, once the private lending occurred; the borrower actually has put its credibility and moral as collateral. They think the private lending is not only a business transaction, but also is a test of the morality for oneself. Muslim private lending keeps a high repayment rate in the condition of spontaneous state, and lack of formal legal due to the Islamic culture.

\section{Countermeasures and Suggestions}

Muslim private lending under the influence of Islamic culture continued to grow with the social economy development in Muslim area, and it plays an indispensable role in promoting the development of Muslim ethnic economy. Guiding adapted to local conditions and setting up micro-credit companies with characteristic of Islamic culture. Playing the Islamic cultural concept and promoting the development of private, Influenced by Islamic culture. The unique advantage of Muslim private lending is to extrude the capital characteristics of aid. In condition of market economy, the concept of humanistic care is particularly valuable. Strengthening the exploration and research and innovating tools of Muslim private lending financing. Muslim private lending should take example by these financial instruments in Islamic financial markets, introducing local Muslim folk lending financing. Enhancing the level of policy support to guide and expansion the fields of the capital investment. Strengthening supervision and management and establishing the monitoring Muslim private lending and increasing the number of monitoring stations.

\section{Acknowledgements}

This work was supported by the Fundamental Research Funds for the Central Universities of Northwest Minzu University (Grant No. 31920170127).

\section{References}

[1] Alkassim, F. A, The profitability of Islamic and conventional banking in the GCC countries: a comparative study. Journal of Review of Islamic Economics, 13 (2005) 5-30.

[2] X.C. Cao, On Islamic Finance and its Introduction in Ningxia, Journal of Beifang Ethnic University, 14 (2009) 52-54.

[3] L.L. Feng, Contradiction of Religion and Development-Discussion on the Theory, Culture and Practical Conflict of Islam and Financial Globalization, Social Sciences in Ningxia, 4(2004) 65-69.

[4] Hassan, M. K., \& Bashir, A. H. M, Determinants of Islamic banking profitability. In the ERF Annual Conference, 16 (2003)161-172.

[5] Y.X. Ma, X.Y. Qi, On Islamic Finance Ideology Studies, Journal of Beifang Ethnic University, 4(2009)43-47.

[6] J.Y. Wang, an introduction of Islamic finance based on PLS model, International finance study, 9 (2005)42-49.

[7] Y.G. Wu, The International Financial Movements in Postwar Period, world religious study, Vol.2 (1989)45-52.

[8] L.L. Xu, An analysis of Islamic financial system in Malaysia, Southeast Asia Research, 1(2004)77-82.

[9] X.F. Zhang, Research to Introduce Islamic Financial Operation Mode-An Example of Ningxia, Economic research, 11 (2009)97-99. 